\title{
The Outer Membranes of Brucella spp. Are Resistant to Bactericidal Cationic Peptides
}

\author{
G. MARTÍNEZ DE TEJADA ${ }^{1} \dagger$ J. PIZARRO-CERDÁ, ${ }^{2} \ddagger$ E. MORENO, ${ }^{2}$ AND I. MORIYÓN ${ }^{1 *}$ \\ Departamento de Microbiología, Universidad de Navarra, Pamplona, Spain, ${ }^{1}$ and Programa de \\ Investigación en Enfermedades Tropicales (PIET), Escuela de Medicina Veterinaria, \\ Universidad Nacional, Heredia, Costa Rica ${ }^{2}$
}

Received 3 January 1995/Returned for modification 27 February 1995/Accepted 18 May 1995

\begin{abstract}
The actions of polymyxin $B$, rabbit polymorphonuclear lysosome extracts, 14 polycationic peptides (including defensin NP-2, cecropin P1, lactoferricin B, and active peptides from cationic protein 18 and bactenecin), EDTA, and Tris on Brucella spp. were studied, with other gram-negative bacteria as controls. Brucella spp. were comparatively resistant to all of the agents listed above and bound less polymyxin $B$, and their outer membranes (OMs) were neither morphologically altered nor permeabilized to lysozyme by polymyxin $B$ concentrations, although both effects were observed for controls. EDTA and peptides increased or accelerated the partition of the hydrophobic probe $N$-phenyl-naphthylamine into Escherichia coli and Haemophilus influenzae OMs but had no effect on Brucella OMs. Since Brucella and $H$. influenzae OMs are permeable to hydrophobic compounds (G. Martínez de Tejada and I. Moriyón, J. Bacteriol. 175:5273-5275, 1993), the results show that such unusual permeability is not necessarily related to resistance to polycations. Although rough (R) B. abortus and $B$. ovis were more resistant than the controls were, there were qualitative and quantitative differences with smooth (S) brucellae; this may explain known host range and virulence differences. Brucella S-lipopolysaccharides (LPSs) had reduced affinities for polycations, and insertion of Brucella and Salmonella montevideo S-LPSs into the OM of a Brucella R-LPS mutant increased and decreased, respectively, its resistance to cationic peptides. The results show that the core lipid A of Brucella LPS plays a major role in polycation resistance and that $\mathrm{O}$-chain density also contributes significantly. It is proposed that the features described above contribute to Brucella resistance to the oxygen-independent systems of phagocytes.
\end{abstract}

Brucella spp. are gram-negative pathogens that infect both animals and humans (5). This genus includes species whose outer membranes (OMs) contain smooth lipopolysaccharides (S-LPSs) (B. abortus, B. melitensis, B. suis, and B. neotomae) as well as others (B. ovis and $B$. canis) that lack true $\mathrm{O}$ chains and are designated naturally rough $(\mathrm{R})$ brucellae because of their similarities with $\mathrm{R}$ mutants of the S Brucella species (5). The survival of Brucella spp. within mononuclear cells has been well documented $(3,5,32-34)$, and it has been shown that B. abortus cells elicit little respiratory burst and only reduced (34) but significant (25) levels of degranulation in polymorphonuclear (PMN) leukocytes. Moreover, Riley and Robertson $(33,34)$ found that compared with R-LPS Salmonella typhimurium mutants, both S-LPS and R-LPS B. abortus cells are resistant to the oxygen-independent mechanisms of PMN cells. More recently, Rasool et al. (32) found that highly purified preparations of $B$. abortus S-LPS are at least 200 times less active in stimulating PMN cells than $S$. typhimurium S-LPS preparations are, an observation that explains the reduced respiratory burst and degranulation induced by $B$. abortus (33).

The resistance of Brucella spp. to oxygen-independent mechanisms has not been explained on a structural basis. Oxygenindependent mechanisms include the synergistic actions of sev-

\footnotetext{
* Corresponding author. Mailing address: Departamento de Microbiología, Universidad de Navarra, Aptdo. 273, 31080 Pamplona, Spain. Phone: 34-48-105600. Fax: 34-48-105649. Electronic mail address: iMORiYON@MAiL1.CTi.UNAV.ES.

$\dagger$ Present address: Department of Microbiology and Immunology, UCLA School of Medicine, Center for the Health Sciences, Los Angeles, Calif.

$\ddagger$ Present address: Centre d'Immunologie de Marseille-Luminy, 13288 Marseille, France.
}

eral cationic proteins and peptides which, in a first step, bind to $\mathrm{OM}$ anionic targets and render the cell envelope permeable and susceptible to lytic enzymes, thereby blocking cell functions that depend on membrane integrity $(11,18,40,45)$. Accordingly, the virulence of some intracellular gram-negative bacteria, such as Salmonella spp., is linked in part to resistance to cationic peptides $(11,41)$, including not only peptides from phagocytes but also bactericidal cationic peptides from other animal and bacterial sources that act first on the OM by a closely related mechanism $(11,45)$. In this work, we probed the OMs of S and R Brucella spp. with various cationic peptides and found reduced affinities for all of them, thereby providing experimental evidence for the hypothesis $(20,32)$ that in Brucella spp., resistance to oxygen-independent systems is linked to the OM and S-LPS properties. In addition, since ionic groups are the target of polycations and part of the OM barrier to hydrophobic agents, we also studied whether the unusual permeability of Brucella OMs to such agents (21) was necessarily related to resistance to polycations. Appropriate controls of other gram-negative bacteria were used throughout these studies.

\section{MATERIALS AND METHODS}

Bacterial strains and growth conditions. The bacterial strains used are listed in Table 1. B. abortus, B. melitensis, Yersinia enterocolitica, Escherichia coli, and Salmonella montevideo were grown in tryptic soy broth (Oxoid Ltd., London, England), and B. ovis and Haemophilus influenzae were grown in the same medium with $0.5 \%$ yeast extract or $3 \%$ nutrient supplement (Fildes; Difco Laboratories, Detroit, Mich.), respectively. Bacteria were harvested $(5,000 \times g$ $15 \mathrm{~min}, 4^{\circ} \mathrm{C}$ ) in the exponential phase of growth and for sensitivity, polymyxin $\mathrm{B}$ binding, and OM stability studies (see below) were resuspended immediately in the appropriate buffer. Alternatively, when sensitivity was tested according to protocol B (see below), bacteria were grown on blood (Brucella spp.) or MacConkey (E. coli) agar plates. For S-LPS extraction, bacteria were propagated in 
TABLE 1. Bacterial strains used in this study

\begin{tabular}{|c|c|c|}
\hline Strain & Characteristics & Reference \\
\hline B. melitensis $16 \mathrm{M}$ & S-LPS, virulent, biotype 1 , serotype $\mathrm{M}$ & 1 \\
\hline B. melitensis Ether & S-LPS, virulent, biotype 3 , serotype AM & 1 \\
\hline B. melitensis 115 & R-LPS, avirulent & 1 \\
\hline B. abortus 2308 & S-LPS, virulent, biotype 1 , serotype A & 19 \\
\hline B. abortus S19 & S-LPS, vaccine strain, biotype 1 , serotype A & 1 \\
\hline B. abortus B3196 & S-LPS, virulent, biotype 5 , serotype $M$ & 1 \\
\hline B. abortus $45 / 20$ & R-LPS, attenuated & 33 \\
\hline B. abortus RB51 & R-LPS, attenuated, derived from B. abortus 2308 & 37 \\
\hline B. ovis Reo 198 & Natural R-LPS species, $\mathrm{CO}_{2}$-independent strain & 1 \\
\hline E. coli $\mathrm{O} 111 \mathrm{~K} 58 \mathrm{H} 2$ & S-LPS, enteropathogenic, used in OM permeability studies & 21 \\
\hline E. coli ATCC 29648 & S-LPS, used in studies of sensitivity to defensins & 38 \\
\hline E. coli $\mathrm{K}-12$ ATCC W1485 & R-LPS of Ra chemotype & \\
\hline S. montevideo SH94 & S-LPS, serogroup D1 & 16 \\
\hline H. influenzae 9193 & Serovar b, clinical isolate & 21 \\
\hline Y. enterocolitica MY79 & Serotype 9, LPS O chain of Brucella serotype A & 26 \\
\hline
\end{tabular}

2-liter flasks (500 ml per flask) on an orbital shaker $(200 \mathrm{rpm})$ and, when appropriate, inactivated with $0.5 \%$ phenol at $37^{\circ} \mathrm{C}$ for $24 \mathrm{~h}$.

LPS preparations. The S-LPSs of B. abortus 2308, S19, E. coli serotype O111, and $S$. montevideo were used as representatives of Brucella- and enterobacterialtype S-LPSs. B. abortus S-LPS (fraction 5) was obtained from the phenol phase of a water-phenol extract and purified by treatment with chaotropic agents and detergents according to published procedures $(22,23)$. Alternatively, fraction 5 was dispersed $(20 \mathrm{mg} / \mathrm{ml})$ by sonication in $5 \mathrm{mM} \mathrm{MgCl}-10 \mathrm{mM}$ Tris- $\mathrm{HCl}(\mathrm{pH}$ $7.5)$ and digested with nucleases $(20 \mu \mathrm{g}$ each of DNase I and RNase A [Sigma Chemical Co., St. Louis, Mo.] per $\mathrm{ml}$ for $4 \mathrm{~h}$ at $\left.37^{\circ} \mathrm{C}\right)$ and proteinase $\mathrm{K}(65 \mu \mathrm{g} / \mathrm{ml}$ [E. Merck, Darmstadt, Germany] for $24 \mathrm{~h}$ at room temperature), and S-LPS was recovered by ultracentrifugation $\left(100,000 \times g, 6 \mathrm{~h}, 4^{\circ} \mathrm{C}\right)$ and freeze dried. By standard analytical methods (6), these S-LPS preparations had 0.8\% 2-keto-3deoxyoctonic acid (KDO), $2.9 \%$ protein, and up to $6 \%$ free lipids distributed among ornithine lipids and the major classes of Brucella phospholipids (43). In some experiments, free lipids were removed by threefold extraction with waterchloroform-methanol (1:1:2). E. coli $\mathrm{O} 111$ and $S$. montevideo S-LPSs were obtained by the standard phenol-water method (6) and purified with nucleases and proteinase $\mathrm{K}$ as described above. These preparations had $1.5 \% \mathrm{KDO}$, less than $1.0 \%$ protein, and trace amounts of free lipids. By sodium dodecyl sulfatepolyacrylamide gel electrophoresis (SDS-PAGE) and silver staining for LPS (44), all of these preparations showed the characteristic pattern of S-LPSs.

Cationic peptides. The characteristics and reported actions of the peptides used are summarized in Table 2. Polymyxin B (sulfate), egg lysozyme, poly-Llysine, poly-L-ornithine, cecropins, melittin, magainins, and lactoferrin were purchased from Sigma. Lactoferricin B was kindly provided by W. Bellamy (Morinaga Dairy Company, Higashihara, Japan), the cationic protein 18 (CAP18) peptide (amino acids 106 through 125) and bactenecin peptides 5 (amino acids 0 through 31) and 7 (amino acids 1 through 35) were provided by R. Gennaro and D. Romeo (Department of Biochemistry, Biophysics, and Chemistry of
Macromolecules, Trieste University, Trieste, Italy), and defensin NP-2 was provided by R. I. Lehrer (Department of Medicine, University of California, Los Angeles).

Lysosomal extract from rabbit PMN leukocytes. White New Zealand rabbits weighing $2.5 \mathrm{~kg}$ each were sensitized by three intraperitoneal injections of $150 \mathrm{ml}$ of $0.1 \%$ oyster glycogen in sterile saline at $37^{\circ} \mathrm{C}$ administered at weekly intervals. Four hours after the last injection, each rabbit was anesthetized, the peritoneal cavity was cannulated, and the exudate was collected in saline with $50 \mathrm{mg}$ of heparin per liter. Over $90 \%$ of cells were PMN leukocytes, as judged by Giemsa staining of smears. After assessment of cell viability (trypan blue exclusion test), PMN leukocytes were suspended $\left(10^{7}\right.$ to $10^{8}$ cells per ml) in $0.34 \%$ sucrose and disrupted in a Potter-type homogenizer. The homogenate was clarified $(125 \times g$, $\left.15 \mathrm{~min}, 4^{\circ} \mathrm{C}\right)$, cytoplasmic granules were sedimented $\left(20,000 \times \mathrm{g}, 30 \mathrm{~min}, 4^{\circ} \mathrm{C}\right)$, and cationic components were extracted with $\mathrm{HCl}$ as described previously (14).

Sensitivity assays. Depending on the amount of peptide available, bacterial sensitivity was measured as the effect of increasing concentrations of an agent on cell viability (protocol A) and/or as the percentage of cell viability after exposure to a single concentration of each agent (protocol B).

(i) Protocol A. The assay described by Riley and Robertson (34) was used with some modifications. Stock solutions of agents were prepared in sterile $0.133 \mathrm{M}$ $\mathrm{NaCl}-0.1 \mathrm{M} \mathrm{NaH}_{2} \mathrm{PO}_{4}(\mathrm{pH} 4.6)$ or $10 \mathrm{mM}$ phosphate buffer ( $\left.\mathrm{pH} 7.0\right)$, and serial dilutions were made directly in sterile 96-well tissue culture clusters (Costar, Cambridge, Mass.) by using the same buffer as a diluent (100 $\mu \mathrm{l}$ per well). Bacteria were resuspended in the same buffer solution at approximately $4 \times 10^{4}$ $\mathrm{CFU} / \mathrm{ml}, 100 \mu \mathrm{l}$ of this suspension was dispensed in duplicated series of wells (4 $\times 10^{3} \mathrm{CFU}$ per well in $200 \mu \mathrm{l}$ ), and plates were incubated for $1 \mathrm{~h}$ at $37^{\circ} \mathrm{C}$. Viable counts were performed by spreading $100 \mu \mathrm{l}$ from each well on tryptic soy agar (Oxoid Ltd.) plates, and the results were expressed as the percentage of survival with respect to that of controls incubated without the appropriate agent (no bacterial multiplication occurred under those conditions).

TABLE 2. Origins and relevant characteristics of cationic peptides

\begin{tabular}{|c|c|c|c|}
\hline Peptide(s) & Origin(s) & Relevant features & Reference(s) \\
\hline Bactenecin & Bovine neutrophils & $\begin{array}{l}\text { Amphiphilic; bactericidal for gram-negative bacteria; permeabilizes OMs } \\
\text { and cytoplasmic membranes }\end{array}$ & 10 \\
\hline CAP18 & Rabbit PMN cells & Bactericidal; binds to LPS; increases cell permeability & 13 \\
\hline Cecropin P1 & Pig intestine & Bactericidal; forms channels in lipid bilayers & 17,39 \\
\hline Cecropin A & Cecropia moth hemolymph & $\begin{array}{l}\text { Amphiphilic (two alpha-helices); bactericidal; forms voltage-dependent } \\
\text { channels in lipid bilayers }\end{array}$ & 2 \\
\hline Defensin NP-2 & PMN cells & Binds to LPS; forms voltage-dependent channels in lipid bilayers & 15,38 \\
\hline Lactoferrin & Milk and mucosal secretions & $\begin{array}{l}\text { Complex structure (alpha-helix and beta-sheet); } \mathrm{Fe} \text { and divalent cation che- } \\
\text { lator; bactericidal; binds to OMs }\end{array}$ & $9,28,48$ \\
\hline Lactoferricin B & & OM-binding peptide derived from lactoferrin & 48 \\
\hline Lysozyme & Egg white & Muramidase; binds to LPS & 42 \\
\hline Magainins 1 and 2 & Frog skin and stomach & $\begin{array}{l}\text { Amphiphilic alpha-helix; bactericidal; binds to LPS; forms channels in } \\
\text { membranes }\end{array}$ & 31,45 \\
\hline Melittin & Bee venom & $\begin{array}{l}\text { Amphiphilic (two alpha-helices); bactericidal; binds to LPS; forms voltage- } \\
\text { dependent channels in membranes }\end{array}$ & $7,12,45$ \\
\hline Poly-L-lysine & Synthetic & Alpha-helix; bactericidal for gram-negative bacteria; binds to LPS & 45 \\
\hline Poly-L-ornithine & Synthetic & Bactericidal for gram-negative bacteria & 45 \\
\hline Polymyxin B & Bacteria & Amphiphilic lipopeptide; bactericidal; binds to LPS; produces OM blebbing & 45 \\
\hline
\end{tabular}


(ii) Protocol B. Bacteria were suspended in $10 \mathrm{mM}$ phosphate buffer ( $\mathrm{pH} 7.0)$ at approximately $4 \times 10^{6} \mathrm{CFU} / \mathrm{ml}$, and $100-\mu \mathrm{l}$ aliquots were mixed with 10 to 20 $\mu \mathrm{g}$ of the appropriate agent (suspended in $3 \mu \mathrm{l}$ of deionized distilled water), and the mixture was incubated at $37^{\circ} \mathrm{C}$ for 20 or $180 \mathrm{~min}$, depending on the agent (see footnotes to Table 3). For CFU counting, the suspension was diluted with $900 \mu \mathrm{l}$ of buffer and $100 \mu \mathrm{l}$ was plated out. All experiments were run in quadruplicate, and the results were expressed as the percentage of inhibition (mean \pm standard deviation) of controls without the agent.

Binding of polymyxin by viable cells. Cell suspensions $\left(4.5 \times 10^{10} \mathrm{CFU} / \mathrm{ml}\right.$ for Brucella spp. and $10^{10} \mathrm{CFU} / \mathrm{ml}$ for $E$. coli and $Y$. enterocolitica serotype O:9) were prepared in $0.133 \mathrm{M} \mathrm{NaCl}-0.1 \mathrm{M} \mathrm{NaH}_{2} \mathrm{PO}_{4}$ (pH 4.6), and serial dilutions were made in 2-ml Eppendorf-type tubes by using the same buffer solution. An equal amount of polymyxin $\mathrm{B}$ was added to each tube $(350 \mathrm{U} / \mathrm{ml}$ of cell suspension), and after incubation for $30 \mathrm{~min}$ at $37^{\circ} \mathrm{C}$, cells were removed by centrifugation $(12,000 \times g, 15 \mathrm{~min})$. To measure unbound polymyxin $\mathrm{B}, 3-\mathrm{mm}$-diameter wells were punched on petri dishes with peptone-glucose-agar containing $10^{7} \mathrm{CFU}$ of E. coli K-12 per ml, $50-\mu l$ aliquots of supernatants were dispensed into wells, and plates were incubated overnight. The amount of polymyxin B was estimated from the diameter of the inhibition halo by comparison with polymyxin B standards on the same plate.

Assessment of OM damage. (i) Electron microscopy. Bacteria were resuspended in $10 \mathrm{mM}$ phosphate-buffered saline (PBS; pH 7.2) and incubated with polymyxin $\mathrm{B}(500 \mathrm{U} / \mathrm{ml})$ for $20 \mathrm{~min}$ at $37^{\circ} \mathrm{C}$. Cells were sedimented $(12,000 \times \mathrm{g}$, $5 \mathrm{~min}$ ), fixed first in $4 \%$ glutaraldehyde- $0.1 \mathrm{M}$ cacodylate buffer ( $\mathrm{pH} 7.2)$ for $1 \mathrm{~h}$ at $4^{\circ} \mathrm{C}$, washed with $2 \mathrm{M}$ sucrose $-50 \mathrm{mM}$ cacodylate $(\mathrm{pH} 7.2)$, and fixed again in $1 \% \mathrm{OsO}_{4}-100 \mathrm{mM}$ cacodylate $(\mathrm{pH} 7.2)$ for $2 \mathrm{~h}$ at $4^{\circ} \mathrm{C}$. The fixing solution was

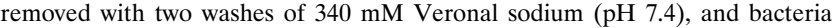
were stained with $0.5 \%$ uranyl acetate in the same buffer $\left(30 \mathrm{~min}, 4^{\circ} \mathrm{C}\right)$. After two additional Veronal washes, bacteria were resuspended in molten Noble agar (Difco Labortories), the gel was included in Epon-812, and thin sections were contrasted with uranyl acetate. Observations were carried out with a Zeiss EM10CR electron microscope (Carl Zeiss Germany, Oberkochen, Germany).

(ii) Permeability to lysozyme. Exponentially growing cells were resuspended in $10 \mathrm{mM} N$-2-hydroxyethylpiperazine- $N$ '-2-ethanesulfonic acid (HEPES; $\mathrm{pH} 7.2$ ) at an optical density (at $500 \mathrm{~nm})$ of 0.8 , and lysozyme $(50 \mu \mathrm{g} / \mathrm{ml})$ and polymyxin $\mathrm{B}(100 \mathrm{U} / \mathrm{ml})$ were added. Incubation was performed at room temperature, and cell lysis was monitored by measuring the $A_{500}$. Since sensitivity to lysozyme has been shown for Brucella spp. (8) and E. coli, cell lysis was taken as evidence of lysozyme uptake (46). Controls were bacterial suspensions with only lysozyme or polymyxin B or without either agent.

(iii) Fluorimetry. Exponentially growing cells were resuspended in $1 \mathrm{mM}$ $\mathrm{KCN}-10 \mathrm{mM}$ PBS (pH 7.2) (Brucella spp. and H. influenzae) or $1 \mathrm{mM} \mathrm{KCN}-10$ $\mathrm{mM}$ HEPES (pH 7.2) (E. coli) at an optical density (at $600 \mathrm{~nm}$ ) of 0.48 and transferred immediately to 1-cm-diameter fluorimetric cuvettes. After 15 to $20 \mathrm{~s}$, $N$-phenyl-naphthylamine (NPN; $500 \mu \mathrm{M}$ in acetone) was added to a final concentration of $10 \mu \mathrm{M}$. Peptides and EDTA were added either before or after NPN at the following final concentrations to cuvettes: EDTA, $5 \mathrm{mM}$; polymyxin B, 100 $\mathrm{U} / \mathrm{ml}$; melittin, $10 \mu \mathrm{g} / \mathrm{ml}$; cecropin $\mathrm{P} 1,6.5 \mu \mathrm{g} / \mathrm{ml}$; magainins 1 and $2,30 \mu \mathrm{g} / \mathrm{ml}$ (each); and lysosomal extract, $20 \mu \mathrm{g}$ of protein per ml. In preliminary experiments, the concentrations of peptides listed above were selected because they were bactericidal (see Results) and did not generate quenching. Fluorescence was monitored at $20^{\circ} \mathrm{C}$ with an LS-50 fluorimeter (Perkin-Elmer Ltd., Beaconsfield, England) set as follows: excitation, $350 \mathrm{~nm}$; emission, $420 \mathrm{~nm}$; slit width, $2.5 \mathrm{~nm}$. The results were expressed in relative fluorescence units (RFU).

Binding of polymyxin $B$ and cationic peptides by S-LPSs. Appropriate amounts of S-LPS were dispersed by ultrasonic treatment $(10 \mathrm{~W}, 20 \mathrm{~s})$ in deionized distilled water or $0.133 \mathrm{M} \mathrm{NaCl}-0.1 \mathrm{M} \mathrm{NaH}_{2} \mathrm{PO}_{4}(\mathrm{pH} \mathrm{4.6)}$, and the solutions were clarified by brief centrifugation $(12,000 \times g, 15 \mathrm{~s})$. By using those suspensions, $5 \mu \mathrm{g}$ of the agent to be tested was mixed with 1.25 to $25.0 \mu \mathrm{g}$ of S-LPS in a volume of $50 \mu \mathrm{l}$, aliquots of this mixture were dispensed into wells punched in peptone-glucose-agar plates previously inoculated with $E$. coli as described above, and plates were incubated overnight. For each agent, the effect of S-LPS was estimated as the percentage of reduction in the halo of inhibition with respect to that obtained with the corresponding agent and no LPS.

The amount of polymyxin B bound by S-LPS was measured by high-performance liquid chromatography (HPLC). Aliquots of S-LPS suspensions were incubated $\left(10 \mathrm{~min}, 37^{\circ} \mathrm{C}\right)$ with increasing amounts of polymyxin $\mathrm{B}$, and the unbound lipopeptide was separated on a TSK3000SW column $(30.0$ by $0.8 \mathrm{~cm})$ (TosoHaas GmbH, Stuttgart, Germany) fitted to a 625 LC unit (Waters Associates, Inc., Milford, Mass.) with a Waters 486 detector set at $220 \mathrm{~nm}$ (previously calibrated by using polymyxin $\mathrm{B}$ as the standard). HPLC was performed at 0.5 $\mathrm{ml} / \mathrm{min}$ in $13 \mathrm{mM} \mathrm{NaCl}-10 \mathrm{mM} \mathrm{NaH} \mathrm{PO}_{4}(\mathrm{pH} 4.6)$.

Coating of $\mathbf{R} B$. abortus with S-LPSs. One hundred microliters of a B. abortus $45 / 20$ suspension $\left(8 \times 10^{7} \mathrm{CFU} / \mathrm{ml}\right.$ in $10 \mathrm{mM}$ phosphate buffer $\left.[\mathrm{pH} 7.0]\right)$ was mixed with $100 \mu \mathrm{l}$ of a suspension $(20 \mathrm{mg} / \mathrm{ml})$ of S-LPS from either B. abortus S19 or $S$. montevideo, and the mixture was sonicated briefly (three pulses of $1 \mathrm{~s}$ ). After incubation for $18 \mathrm{~h}$ at $40^{\circ} \mathrm{C}$, cells were washed three times and resuspended in $200 \mu \mathrm{l}$ of $10 \mathrm{mM}$ phosphate buffer ( $\mathrm{pH} 7.0$ ), and $100 \mu \mathrm{l}$ of this suspension was incubated for $20 \mathrm{~min}$ with $10 \mu \mathrm{g}$ of the agent to be tested and then plated out for CFU counting. Experiments were run in quadruplicate, and the results were expressed as the percentage of inhibition (mean \pm standard deviation) of controls without the agent. Insertion of S-LPS into the OM of B. abortus $45 / 20$ was
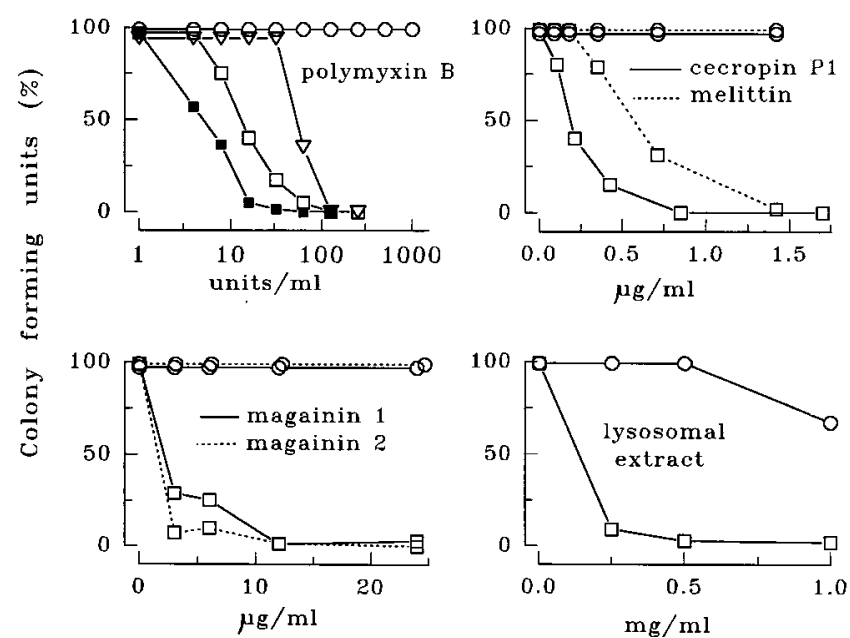

FIG. 1. Effects of polymyxin B (upper left panel), melittin and cecropin P1 (upper right panel), magainins 1 and 2 (lower left panel), and lysosomal extract (lower right panel) on the viabilities of B. abortus $2308(\bigcirc)$, Y. enterocolitica O:9 $(\nabla)$, E. coli K-12 (ם), and E. coli O111 K58H2 ( $\square)$.

shown by immunofluorescence (16) with either rat monoclonal antibody to the $S$. montevideo O chain (D1 serogroup) (kindly provided by A. Weintraub, Department of Clinical Bacteriology, Karolinska Institute, Huddinge Hospital, Huddinge, Sweden) or mouse monoclonal antibody to the $B$. abortus O-chain common $\mathrm{C} / \mathrm{Y}$ epitope (35) and rabbit anti-rat immunoglobulin $\mathrm{G}$ or anti-mouse immunoglobulin-fluorescein isothiocyanate conjugates (Sigma). Compared with that of uncoated controls, coating had no effect on the viability of $B$. abortus $45 / 20$

\section{RESULTS}

Effects of EDTA, polymyxin B, and cationic peptides on cell viability. The effects of increasing concentrations of polymyxin $\mathrm{B}$ on the viabilities of $B$. abortus $2308, \mathrm{~S}$ and $\mathrm{R} E$. coli, and $Y$. enterocolitica $\mathrm{O}: 9$ are illustrated in Fig. 1. In this assay, $B$. abortus 2308 was remarkably more resistant than the controls were, and identical results were obtained with the remaining $\mathrm{S}$ and $\mathrm{R}$ Brucella strains within the range of concentrations tested (data not shown). It can also be seen that the $E$. coli $\mathrm{R}$ strain was more sensitive than the $\mathrm{S}$ strain was and that $B$. abortus $\mathrm{O}$-chain-bearing $Y$. enterocolitica $\mathrm{O}: 9$ was less affected by polymyxin B than $E$. coli was at concentrations of less than $50 \mathrm{U} / \mathrm{ml}$. Similar experiments were performed with melittin, cecropin P1, magainins, and lysosomal extract (Fig. 1), and the results resembled those obtained with polymyxin B in that $B$. abortus was resistant to peptide and lysosomal extract concentrations that were lethal for $E$. coli.

Table 3 shows the effects of a single concentration of each cationic peptide, Tris, and EDTA on the viabilities of $\mathrm{S} B$. abortus, an R B. abortus mutant, and $B$. ovis. It can be seen that the three Brucella strains were more resistant to all of the agents tested than the $E$. coli control was, with the conspicuous exception of bactenecin 7 and $B$. ovis. This peptide reduced the growth of $E$. coli by $97 \%$, and although it had a limited effect on $\mathrm{S}$ and $\mathrm{R} B$. abortus, it showed maximal activity on $B$. ovis (100\% growth reduction). The peptides that were more active on S B. abortus (strain S19) were polymyxin B and lactoferricin $\mathrm{B}$, and although the results of both protocols were in good agreement (Fig. 1 and Table 3), protocol $\mathrm{B}$ also showed that the $\mathrm{S} B$. abortus strain was more resistant than the homologous $\mathrm{R}$ strain was (Table 3 ). B. ovis showed a sensitivity spectrum somewhat different from that of $B$. abortus, since in addition to bactenecin 7 , it was comparatively sensitive to poly-L-ornithine and poly-L-lysine. No pattern of activity that related to the 
TABLE 3. Activities of cationic peptides, EDTA, and Tris against $E$. coli and $\mathrm{S}$ and $\mathrm{R}$ brucellae ${ }^{a}$

\begin{tabular}{|c|c|c|c|c|}
\hline \multirow[b]{2}{*}{ Agent } & \multicolumn{4}{|c|}{ Activity against: } \\
\hline & E. coli & $\begin{array}{l}\text { B. abortus } \\
\text { S19 }\end{array}$ & $\begin{array}{l}\text { B. abortus } \\
45 / 20\end{array}$ & $\begin{array}{c}\text { B. ovis } \\
\text { Reo } 198\end{array}$ \\
\hline Bactenecin 7 & $97.3 \pm 0.7$ & $1.4 \pm 0.8$ & $8.6 \pm 2.2$ & $100 \pm 0.0$ \\
\hline Bactenecin 5 & $76.8 \pm 5.2$ & $0.6 \pm 0.7$ & $5.9 \pm 1.1$ & $11.9 \pm 1.4$ \\
\hline CAP18 & $91.1 \pm 3.0$ & $1.1 \pm 0.8$ & $9.9 \pm 1.7$ & $14.3 \pm 2.5$ \\
\hline Cecropin $\mathrm{A}^{b}$ & 100 & 0.4 & 0.5 & 0.6 \\
\hline Cecropin $\mathrm{P} 1^{b}$ & 97.8 & 4.9 & 22.5 & 24.0 \\
\hline Defensin NP-2c & $93.9 \pm 3.7$ & $0.6 \pm 0.4$ & $1.5 \pm 0.3$ & $\mathrm{ND}^{d}$ \\
\hline Lactoferricin $\mathrm{B}^{e}$ & $93.9 \pm 1.2$ & $10.9 \pm 1.5$ & $23.1 \pm 1.0$ & $25.6 \pm 0.5$ \\
\hline Lactoferrin $^{f}$ & $85.8 \pm 1.9$ & $0.6 \pm 0.3$ & $9.5 \pm 0.7$ & $15.6 \pm 2.3$ \\
\hline Lysozyme $^{g}$ & $81.1 \pm 2.5$ & $7.0 \pm 2.2$ & $27.6 \pm 1.5$ & $30.3 \pm 1.8$ \\
\hline Magainin $1^{b}$ & 84.9 & 0.0 & 0.5 & 0.9 \\
\hline Magainin $2^{b, e}$ & 93.7 & 1.0 & 1.3 & 2.4 \\
\hline Melittin & $100.0 \pm 0.0$ & $0.6 \pm 0.3$ & $23.9 \pm 1.0$ & $32.8 \pm 1.5$ \\
\hline Poly-L-lysine & $99.6 \pm 0.3$ & $0.5 \pm 0.3$ & $0.95 \pm 1.3$ & $55.9 \pm 2.3$ \\
\hline Polymyxin B & $100.0 \pm 0.0$ & $19.0 \pm 2.1$ & $31.6 \pm 2.5$ & $39.9 \pm 2.6$ \\
\hline Poly-L-ornithine & $99.5 \pm 0.4$ & $0.9 \pm 0.7$ & $14.7 \pm 3.4$ & $57.2 \pm 4.1$ \\
\hline EDTA $^{g}$ & $97.3 \pm 0.8$ & $0.9 \pm 0.7$ & $2.6 \pm 1.4$ & $6.7 \pm 4.6$ \\
\hline Tris $^{g}$ & $76.6 \pm 2.0$ & $1.4 \pm 1.1$ & $2.2 \pm 2.1$ & $3.4 \pm 1.5$ \\
\hline
\end{tabular}

${ }^{a}$ Unless indicated otherwise, activity is expressed as the percentage of inhibition (mean \pm standard deviation) after exposure for $20 \mathrm{~min}$ to $10 \mu \mathrm{g}$ of the indicated agent per $\mathrm{ml}$.

${ }^{b}$ Only one assay was performed.

${ }^{c}$ Incubation was carried out for $90 \mathrm{~min}$.

${ }^{d} \mathrm{ND}$, not done.

${ }^{e}$ Incubation was carried out for $180 \mathrm{~min}$

${ }^{f}$ Incubation was carried out for $180 \mathrm{~min}$ with $10 \mu \mathrm{g}$ of the agent per $\mathrm{ml}$ and 10 $\mu \mathrm{g}$ of lysozyme per $\mathrm{ml}$.

${ }^{g}$ Incubation was carried out for $180 \mathrm{~min}$ with $200 \mu \mathrm{g}$ of the agent per ml.

known structural features (Table 2) of these peptides was observed.

Binding of polymyxin B by live cells. The results of polymyxin B binding experiments are presented in Fig. 2. Whereas $10^{10} \mathrm{CFU}$ of $E$. coli and Y. enterocolitica O:9 bound over $300 \mathrm{U}$ of polymyxin B, the same number of Brucella CFU bound less than $50 \mathrm{U}$ of polymyxin B. No differences between $\mathrm{S} B$. abortus and $B$. melitensis and their respective $\mathrm{R}$ mutants were observed within the range of polymyxin B concentrations tested (Fig. 2).

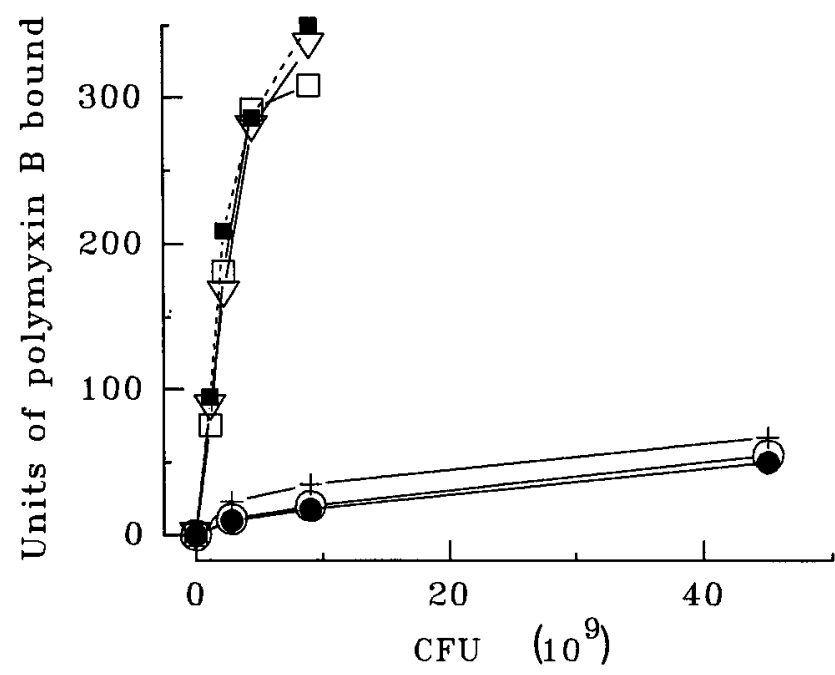

FIG. 2. Polymyxin B binding by increasing amounts of viable cells of $B$. abortus $2308(\bigcirc)$, B. abortus RB51 (৩), B. melitensis $115(+)$, Y. enterocolitica O:9 $(\nabla)$, E. coli $\mathrm{K}-12(\mathbf{\square})$, and E. coli $\mathrm{O} 111(\square)$.
In these experiments, HPLC and SDS-PAGE analyses of the supernatants of cells treated with polymyxin B showed the release of large amounts of medium- to low-molecular-weight materials by $E$. coli, not B. abortus (data not shown).

Assessment of OM damage by EDTA, polymyxin B, and cationic peptides. Figures $3 \mathrm{~A}$ and $\mathrm{B}$ are electron microscope pictures of E. coli $\mathrm{O} 111$ and B. abortus 2308 cells exposed to polymyxin $\mathrm{B}$. Whereas this treatment induced extensive OM blebbing in the control, it had no effect on B. abortus 2308 . Figure $3 \mathrm{C}$ shows that polymyxin $\mathrm{B}$ increased the permeability of $E$. coli $\mathrm{O} 111$ to lysozyme, as demonstrated by the turbidity drop (cell lysis) of the cell suspension. In contrast, the turbidity of the B. abortus 2308 suspension remained constant (Fig. 3C). E. coli $\mathrm{K}-12$ and $B$. abortus RB51 also gave equivalent results; viability was $100 \%$ for B. abortus and less than $5 \%$ for E. coli at the end of this experiment.

The possibility of more subtle changes in cell surfaces was studied by examining the partition of NPN into OMs (Fig. 4), with bacteria with OM permeability properties different from (E. coli) and similar to (H. influenzae) those of Brucella spp. used as controls. In the absence of EDTA, polymyxin B, and cationic peptides, only a limited amount of NPN was partitioned into the OM of $E$. coli O111, as shown by the small (20 RFU) increase in fluorescence measured after NPN addition (Fig. 4, upper left panel, discontinuous line). In H. influenzae (Fig. 4, middle panel, discontinuous line), a progressive increase in fluorescence was observed after NPN addition, a result which is due to the accessibility of the hydrophobic pathway in this OM (21). Although the OMs of controls had almost opposite barrier properties, both were stabilized by divalent cations since EDTA caused a small but significant increase in fluorescence in E. coli (up to 45 RFU) (Fig. 4, upper left panel, continuous line) and an acceleration in the kinetics of NPN entry in H. influenzae (Fig. 4, middle left panel, continuous line). In agreement with these results, the peptides tested (polymyxin B, melittin, cecropin P1, and magainins 1 and 2) brought about a sharp increase (up to $120 \mathrm{RFU}$ ) in the entry of NPN into the OM of $E$. coli O111 (Fig. 4, upper right panel) and accelerated NPN uptake in H. influenzae (Fig. 4, middle right panel). In contrast, although NPN partitioned spontaneously into B. abortus OMs (Fig. 4, lower left panel, discontinuous line), the kinetics of NPN uptake into B. abortus 2308 OMs was not altered by either EDTA or the peptides tested (Fig. 4, lower panels, continuous lines). Additional controls performed with heat-shocked B. abortus 2308 showed a quick increase in fluorescence (Fig. 4, lower right panel, discontinuous line), confirming that OM damage accelerates the partition of NPN into the OM. Similar results were obtained with the remaining $B$. abortus and $B$. melitensis strains (data not shown). Finally, NPN uptake by $E$. coli $\mathrm{O} 111$ was promoted by lysosomal extract, particularly in combination with EDTA, but lysosomal extract had no effect on B. abortus 2308 under the same conditions (data not shown).

Binding of polymyxin B and cationic peptides by S-LPSs. As a first approach, the binding of peptides by S-LPSs was assessed as the reduction in peptide antibiotic activity after incubation with the S-LPS tested. At the maximal amount tested $(25 \mu \mathrm{g}), S$. montevideo S-LPS caused 70 to $80 \%$ reductions in the activities of magainins, melittin, CAP18 peptide, cecropins, and polymyxin $\mathrm{B}$ and a $47 \%$ reduction in the activity of lactoferricin B. With $B$. abortus S-LPS, there were reductions of $66 \%$ for polymyxin B; of about $50 \%$ for cecropin P1, magainins, and melittin; and of only $15 \%$ for CAP18 peptide, cecropin $\mathrm{A}$, and lactoferricin B.

Since polymyxin B was the agent with the highest affinity for B. abortus S-LPS, direct measurements of the amounts of poly- 


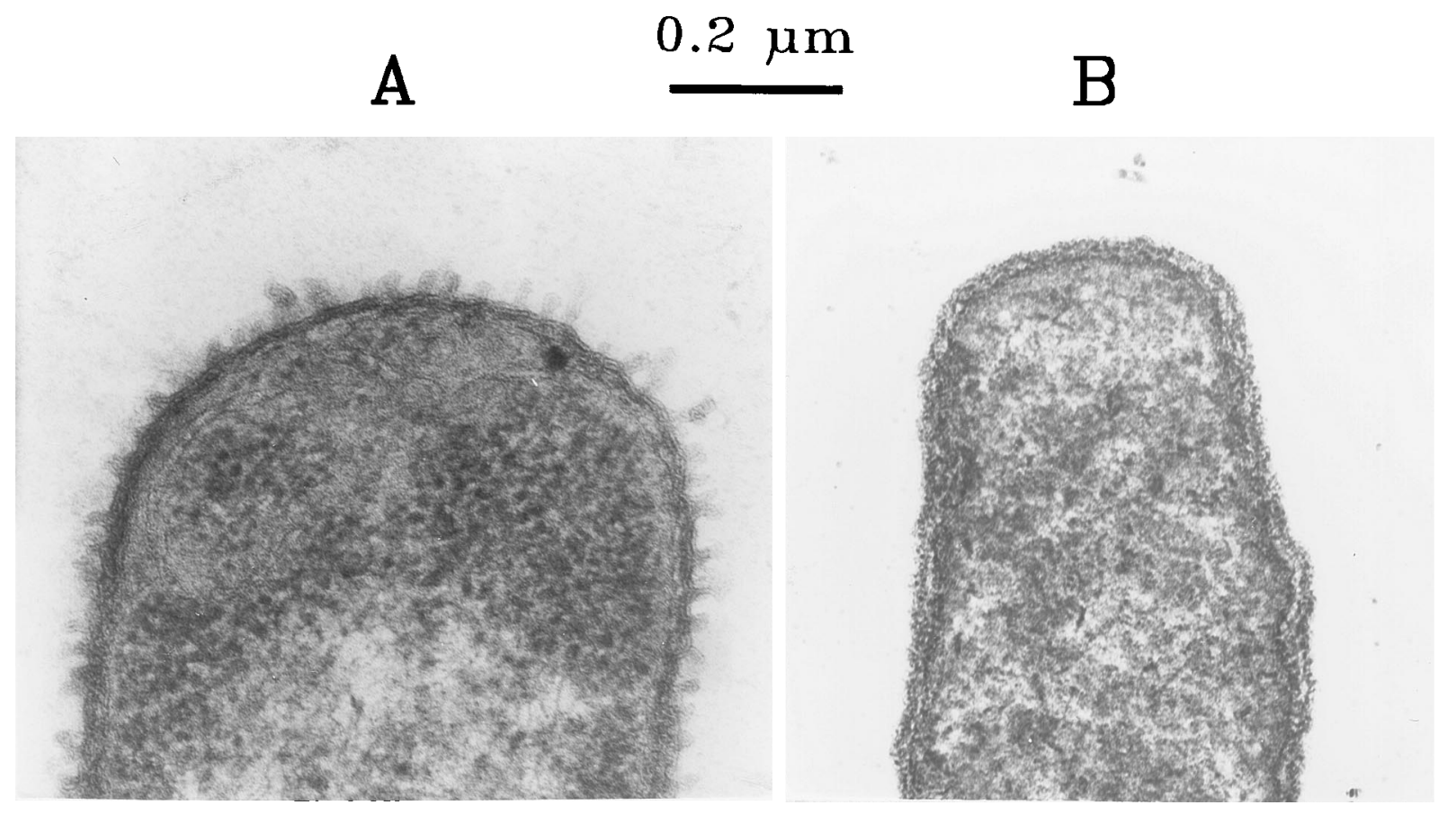

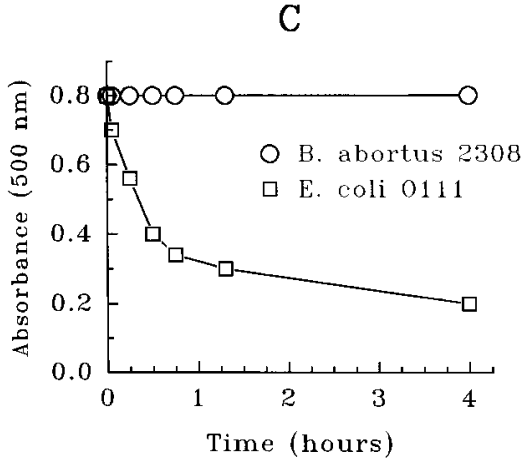

myxin B bound by the S-LPSs of B. abortus 2308 and E. coli O111 were carried out by HPLC analysis of S-LPS-polymyxin $\mathrm{B}$ mixtures. The results showed that on the basis of either dry weight (Fig. 5A) or polymyxin B bound by nanomoles of KDO (Fig. 5B), the S-LPS of B. abortus 2308 bound less polymyxin B than did the S-LPS of E. coli O111. The results did not change substantially when the S-LPSs of B. abortus S19 and $S$. montevideo were used or when $B$. abortus S-LPSs were purified by different protocols. No differences were observed between $B$. abortus S-LPS preparations which contained phospholipids and ornithine lipids and those from which free lipids had been removed by solvent extraction (data not shown).

Effects of polymyxin $B$ and cationic peptides on $R B$. abortus coated with S-LPSs. Compared with the sensitivities of $\mathrm{S} B$. abortus and E. coli, R B. abortus $45 / 20$ had an intermediate sensitivity to polycationic molecules (Table 3). By taking advantage of this observation, an experimental protocol was designed to test the activities (percentages of growth inhibition) of polycations on $\mathrm{R} B$. abortus $45 / 20$ cells coated with S-LPSs from resistant (S B. abortus) and sensitive (enterobacteria) bacteria (Table 4). Coating with $B$. abortus S-LPS brought about significant increases in resistance to the CAP18 peptide, lactoferricin $\mathrm{B}$, melittin, polymyxin $\mathrm{B}$, and poly-L-ornithine
FIG. 3. Effects of polymyxin B on the OMs of B. abortus and E. coli. Electron microscope pictures of $E$. coli $\mathrm{O} 111$ after exposure to polymyxin B at $500 \mathrm{U} / \mathrm{ml}$ for $20 \mathrm{~min}$ at $37^{\circ} \mathrm{C}$ (A) and B. abortus 2308 after exposure to polymyxin $\mathrm{B}$ at 500 $\mathrm{U} / \mathrm{ml}$ for $20 \mathrm{~min}$ at $37^{\circ} \mathrm{C}$ (B). (C) Cell lysis induced by exposure to polymyxin $\mathrm{B}$ $(100 \mathrm{U} / \mathrm{ml})$ and lysozyme $(50 \mu \mathrm{g} / \mathrm{ml})$.

which paralleled the higher resistance observed for the $\mathrm{S} B$. abortus strain in the same sensitivity assay (Table 3 ). In contrast, coating with $S$. montevideo S-LPS rendered B. abortus $45 / 20$ sensitive to the agents tested (Table 4 ) at levels close to those observed for S-LPS enterobacteria (Table 3).

\section{DISCUSSION}

Previous studies have shown that the Brucella cell envelope has permeability properties (21) and sensitivities to detergents and EDTA $(21,24)$ that are different from those common to gram-negative bacteria, and on this basis, a relationship between Brucella OM properties and pathogenicity has been suggested $(20,32)$. In this work, B. abortus, B. melitensis, and $B$. ovis were studied for their resistance to Tris, polymyxin B, lysosomal extract, and bactericidal cationic peptides, including several (bactenecins 5 and 7, CAP18 peptide, cecropin P1, defensin NP-2, lactoferrin, and lysozyme) that are physiological in mammals. In two complementary protocols, those agents manifested their lethal actions on controls (E. coli and $Y$. enterocolitica O:9), but with one exception (bactenecin 7 and $B$. ovis), they showed only limited actions on Brucella spp. The fact that Brucella spp. were equally resistant to peptides with various structures and some differences in reported actions (Table 2) suggests that resistance occurs at an early step common to all of these peptides, and insensitivity to EDTA hinted at the lack of OM ionic groups for electrostatic binding. This hypothesis was tested first with polymyxin B. The results showed that both $\mathrm{R}$ and $\mathrm{S}$ Brucella cells bound comparatively reduced amounts of polymyxin $\mathrm{B}$ and that this potent lipopeptide did not cause OM morphological alterations or permeability to lysozyme under conditions in which both effects were observed for controls. Moreover, the identical kinetics of NPN 

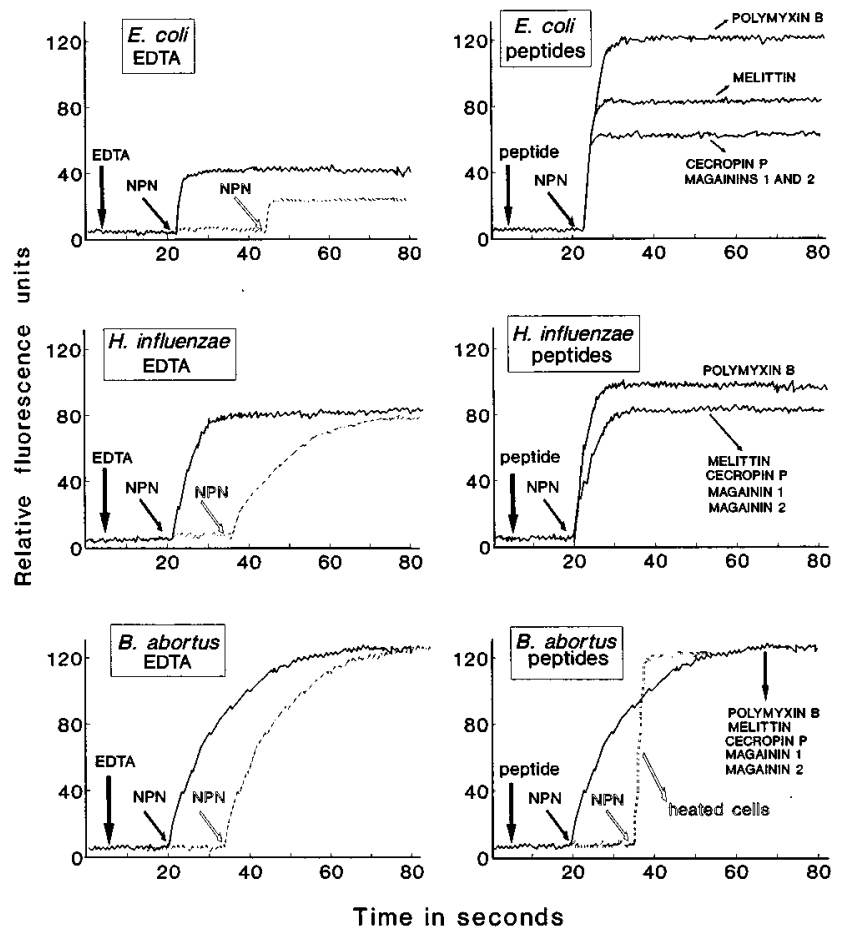

FIG. 4. Effects of EDTA, polymyxin B, and cationic peptides on the partition of NPN into the OMs of live cells of E. coli $\mathrm{O} 111 \mathrm{~K} 58 \mathrm{H} 2$ (upper panels), $H$. influenzae 9193 (middle panels), and B. abortus 2308 (lower panels). Arrows indicate the times of addition of the agent(s) listed and NPN, and fluorescence (in RFU) corresponding to polymyxin B and peptides has been plotted. The discontinuous line in the lower right panel corresponds to a control in which NPN was added to $B$. abortus 2308 cells previously damaged by heating. Discontinuous lines in all other panels are control experiments with viable cells and NPN only.

partition into the OMs of Brucella spp. in the absence and presence of EDTA and cationic peptides contrasted with the effects observed for the two complementary controls used $(E$. coli and $H$. influenzae). Since it is known that little changes in the OMs of gram-negative bacteria caused by cationic peptides instantaneously alter the partition of NPN into the OM $(29,30$,

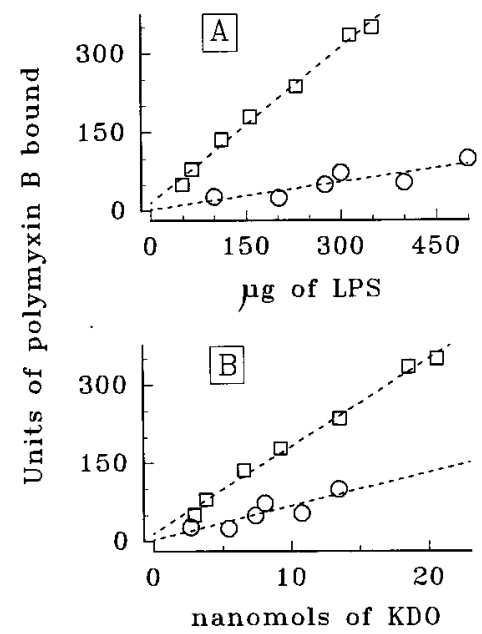

FIG. 5. Polymyxin B binding by enterobacterial-type S-LPS (E. coli) ( $\square$ ) and Brucella-type S-LPS (B. abortus) $(\bigcirc)$ according to LPS dry weight (A) and nanomoles of KDO (B).
TABLE 4. Activities of cationic peptides against R B. abortus 45/20 coated with S-LPSs from S B. abortus and S. montevideo ${ }^{a}$

\begin{tabular}{lrrc}
\hline \multirow{2}{*}{\multicolumn{1}{c}{ Agent }} & \multicolumn{3}{c}{ Coating } \\
\cline { 2 - 4 } & \multicolumn{1}{c}{ None } & $\begin{array}{c}\text { B. abortus } \\
\text { S19 S-LPS }\end{array}$ & $\begin{array}{c}\text { S. montevideo } \\
\text { S-LPS }\end{array}$ \\
\hline Bactenecin 7 & $8.6 \pm 2.2$ & $7.4 \pm 0.9$ & $98.7 \pm 1.1$ \\
CAP18 & $9.9 \pm 1.7$ & $7.2 \pm 0.5^{b}$ & $97.8 \pm 0.5$ \\
Lactoferricin B & $23.1 \pm 1.0$ & $17.2 \pm 0.8^{c}$ & $97.4 \pm 2.3$ \\
Melittin & $31.6 \pm 2.5$ & $16.4 \pm 1.1^{c}$ & $99.1 \pm 0.4$ \\
Polymyxin B & $23.9 \pm 1.0$ & $8.9 \pm 0.7^{c}$ & $99.1 \pm 0.9$ \\
Poly-L-ornithine & $14.7 \pm 3.4$ & $11.1 \pm 2.0^{d}$ & $98.1 \pm 1.4$ \\
\hline
\end{tabular}

${ }^{a}$ See Table 3, footnote $a$.

${ }^{b}$ Significantly different from the results for uncoated controls $(P<0.01)$

${ }^{c}$ Significantly different from the results for uncoated controls $(P<0.001)$.

${ }^{d}$ Significantly different from the results for uncoated controls $(P<0.02)$.

$36,45)$, the results of fluorimetric experiments extend the results obtained in binding experiments with whole cells. The fact that $H$. influenzae and Brucella OMs presented similar levels of permeability to hydrophobic probes but different sensitivities to EDTA and cationic peptides also means that, in general, there is no tight connection between the ionic groups which allow the electrostatic binding of cationic peptides and the impermeability of OMs to hydrophobic agents.

In other gram-negative bacteria, LPS is the major target of several cationic peptides (Table 2); therefore, it is not surprising that LPS plays a role in the resistance of Brucella spp. to polycationic compounds at both the O-chain and core lipid A levels. A role for the $\mathrm{O}$ chain can be postulated since $\mathrm{S} B$. abortus was more resistant than $\mathrm{R} B$. abortus was and since coating the latter with homologous S-LPS increased resistance. Obviously, this could account in part for the wellknown, yet unexplained loss of virulence in R Brucella mutants (5). An overall anionic charge on the surface of $\mathrm{R} \mathrm{B}$. abortus has previously been shown (47); as in other gram-negative bacteria $(4,27,41)$, the $O$ polysaccharide could simply mask inner anionic sites. In addition, the composition of Brucella $\mathrm{O}$ polysaccharide (a homopolymer of $N$-formyl-perosamine [26]) could enhance the effect of polysaccharide length, since $B$. abortus O-chain-bearing Y. enterocolitica O:9 (26) was less affected by subinhibitory polymyxin B concentrations than $E$. coli O111 was. A major role for the core lipid A of Brucella LPS is demonstrated by the resistance of R Brucella mutants and $B$. ovis and by binding experiments with purified LPSs. Since phosphate and KDO are the LPS sites with affinities for polymyxin B and cations $(41,45)$ and the core lipid A of Brucella LPS contains reduced amounts of KDO (23), this could account in part for comparatively reduced affinity. Moreover, the fact that the ratio of bound polymyxin $\mathrm{B}$ to nanomoles of KDO for $E$. coli and $S$. montevideo was higher than that for B. abortus suggests the unavailability on Brucella LPS of anionic binding sites other than KDO, perhaps in relation to the absence of phosphate in lipid A (23). The shielding of LPS anionic groups by cationic ornithine lipids has also been suggested as a mechanism of resistance (20), and although we found that S-LPS purified of lipids had the same reduced affinity for cationic peptides, such shielding could be an additional resistance factor in an intact OM.

The results of this research demonstrate that the OMs of Brucella spp. have properties that are helpful in withstanding the actions of relevant components of the oxygen-independent systems of phagocytes. Moreover, they suggest subtle differ- 
ences among Brucella species. In a previous study, we found differences in the kinetics of NPN partition into the OM between B. ovis on one hand and B. melitensis and B. abortus on the other (21) that could be related to their respective LPS structures, and in this work, we observed that $B$. ovis was extremely sensitive to bovine bactenecin 7. Unfortunately, little is known of the structure of either bovine bactenecin 7 or B. ovis LPS. However, since B. ovis infections are restricted to sheep (5), it is tempting to speculate that differences in $\mathrm{OM}$ and host defense peptides account in part for known differences in virulence and host range among Brucella species (5).

\section{ACKNOWLEDGMENTS}

We are thankful to W. Bellamy, R. Gennaro, R. I. Lehrer, and D. Romeo for some of the peptides; to R. I. Lehrer and J. M. Verger for some of the strains; and to A. Weintraub for antibody to the $S$. montevideo $\mathrm{O}$ chain.

This research was supported by grants from the Dirección General de Investigación Científica y Tecnológica of Spain (PM92-0140-CO2), the Consejo Nacional de Investigaciones Científicas y Tecnológicas (CONICIT) of Costa Rica, the Third World Academy of Sciences (TWAS 92-108 RG/BIO/LA), and INSERM (France). Fellowship support for G.M.T. from the Sociedad de Amigos de la Universidad de Navarra is also acknowledged.

\section{REFERENCES}

1. Alton, G. G., L. M. Jones, R. D. Angus, and J. M. Verger. 1988. Techniques for the brucellosis laboratory. INRA, Paris.

2. Boman, H. G., I. Faye, G. H. Gudmundsson, J.-Y. Lee, and D.-A. Lidholm. 1991. Cell-free immunity in Cecropia. A model for antibacterial proteins. Eur. J. Biochem. 201:23-31.

3. Canning, P. 1990. Phagocyte function in resistance to brucellosis, p. 151-163. In L. G. Adams (ed.), Advances in brucellosis research. Texas A\&M University Press, College Station.

4. Capodici, C., S. Chen, Z. Sidorczyk, P. Elsbach, and J. Weiss. 1994. Effect of lipopolysaccharide (LPS) chain length on interactions of bactericidal/permeability-increasing protein and its bioactive 23-kilodalton $\mathrm{NH}_{2}$-terminal fragment with isolated LPS and intact Proteus mirabilis and Escherichia coli. Infect. Immun. 62:259-265.

5. Corbel, M. J., and W. J. Brinley-Morgan. 1984. Genus Brucella Meyer and Shaw $1920,173^{A L}$, p. 377-387. In N. R. Krieg and J. G. Holt (ed.), Bergey's manual of systematic bacteriology, vol. 1. The Williams \& Wilkins Co., Baltimore.

6. Daniels, L., R. S. Hanson, and J. A. Phillips. 1994. Chemical analysis, p. 512-554. In P. Gerhardt, R. G. E. Murray, W. A. Wood, and N. R. Krieg (ed.), Methods for general and molecular bacteriology. American Society for Microbiology, Washington, D.C

7. David, S. A., V. I. Mathan, and P. Balaram. 1992. Interaction of melittin with endotoxic lipid A. Biochim. Biophys. Acta 1123:269-274.

8. Dubray, G. 1973 . Le peptidoglycane des Brucella: mise en évidence d'une structure à triple feuillet. C. R. Acad. Sci. Ser. D 277:2281-2283.

9. Ellison, R. T., III, and T. J. Giehl. 1991. Killing of gram-negative bacteria by lactoferrin and lysozyme. J. Clin. Invest. 88:1080-1091.

10. Gennaro, R., B. Skerlavaj, and D. Romeo. 1989. Purification, composition, and activity of two bactenecins, antibacterial peptides of bovine neutrophils. Infect. Immun. 57:3142-3146.

11. Groisman, E. A. 1994 . How bacteria resist killing by host-defense peptides. Trends Microbiol. 2:444-448.

12. Hanke, W., C. Methfessel, H.-U. Wilmsen, E. Katz, G. Jung, and G. Boheim. 1983. Melittin and chemically modified trichotoxin form alamethricin-type multistate pores. Biochim. Biophys. Acta 727:108-114.

13. Hirata, M., Y. Shinomura, M. Yoshida, J. G. Morgan, I. Palings, D. Wilson, M. H. Yen, S. C. Wright, and J. W. Larrick. 1994. Characterization of a rabbit cationic protein (CAP18) with lipopolysaccharide-inhibitory activity. Infect. Immun. 62:1421-1426.

14. Hovde, C. J., and B. H. Gray. 1986. Characterization of a protein from normal human polymorphonuclear leukocytes with bactericidal activity against Pseudomonas aeruginosa. Infect. Immun. 54:142-148.

15. Kagan, B. L., M. E. Selsted, T. Ganz, and R. I. Lehrer. 1990. Antimicrobial defensin peptides form voltage-dependent ion-permeable channels in planar lipid bilayer membranes. Proc. Natl. Acad. Sci. USA 87:210-214.

16. Khun, H., B. Samanta, and H. Mayer. 1987. Comparison of enterobacterial common antigen from different species by serological techniques. Eur. J. Biochem. 162:69-74.
17. Lee, J. Y., A. Boman, S. Chuanxin, M. Andersson, H. Jörnvall, V. Mutt, and H. G. Boman. 1989. Antibacterial peptides from pig intestine: isolation of a mammalian cecropin. Proc. Natl. Acad. Sci. USA 86:9159-9162.

18. Lehrer, R. I., A. K. Lichtenstein, and T. Ganz. 1993. Defensin: antimicrobial and cytotoxic peptides of mammalian cells. Annu. Rev. Immunol. 11:105128.

19. Manthei, C. A. 1950. Brucellosis in cattle, p. 172-187. In C. L. Larson and M. H. Soule (ed.), Brucellosis. American Association for the Advancement of Science, Washington, D.C.

20. Martin, N. L., and R. E. W. Hancock. 1990. Function and structure of the major components of the outer membrane of gram-negative bacteria, p. 55-75. In L. G. Adams (ed.), Advances in brucellosis research. Texas A\&M University Press, College Station.

21. Martínez de Tejada, G., and I. Moriyón. 1993. The outer membranes of Brucella spp. are not barriers to hydrophobic permeants. J. Bacteriol. 175: 5273-5275.

22. Moreno, E., D. T. Berman, and L. A. Boettcher. 1981. Biological activities of Brucella abortus lipopolysaccharides. Infect. Immun. 31:362-369.

23. Moreno, E., E. Stackebrandt, M. Dorsch, J. Wolters, M. Busch, and H. Mayer. 1990. Brucella abortus 16S rRNA and lipid A reveal a phylogenetic relationship with members of the alpha-2 subdivision of the class Proteobacteria. J. Bacteriol. 172:3569-3576.

24. Moriyón, I., and D. T. Berman. 1982. Effects of nonionic, ionic, and dipolar ionic detergents and EDTA on the Brucella cell envelope. J. Bacteriol. 152:822-828.

25. Morris, J. A. 1977. The interaction of B. abortus 544 and neutrophil polymorphonuclear leukocytes. Ann. Sclavo 19:143-150.

26. Perry, M. B., and D. R. Bundle. 1990. Lipopolysaccharide antigens and carbohydrates of Brucella, p. 76-88. In L. G. Adams (ed.), Advances in brucellosis research. Texas A\&M University Press, College Station.

27. Peterson, A. A., A. Haug, and E. J. McGroarty. 1986. Physical properties of short- and long-O-antigen-containing fractions of lipopolysaccharide from Escherichia coli 0111:B4. J. Bacteriol. 165:116-122.

28. Pierce, A., D. Colavizza, M. Benaissa, P. Maes, A. Tartar, J. Montreuil, and G. Spik. 1991. Molecular cloning and sequence analysis of bovine lactotransferrin. Eur. J. Biochem. 196:177-184.

29. Piers, K. L., M. H. Brown, and R. E. W. Hancock. 1994. Improvement of outer membrane-permeabilizing and lipopolysaccharide-binding activities of an antimicrobial cationic peptide by C-terminal modification. Antimicrob. Agents Chemother. 38:2311-2316.

30. Piers, K. L., and R. E. W. Hancock. 1994. The interaction of a recombinant cecropin/melittin hybrid peptide with the outer membrane of Pseudomonas aeruginosa. Mol. Microbiol. 12:951-958.

31. Rana, F. R., and J. Blazyk. 1991. Interactions between the antimicrobial peptide, magainin 2, and $S$. typhimurium lipopolysaccharides. FEBS Lett. 293:11-15.

32. Rasool, O., E. Freer, E. Moreno, and C. Jarstrand. 1992. Effect of Brucella abortus lipopolysaccharide on oxidative metabolism and lysozyme release by human neutrophils. Infect. Immun. 60:1699-1702.

33. Riley, L. K., and D. C. Robertson. 1984. Ingestion and intracellular survival of Brucella abortus in human and bovine polymorphonuclear leukocytes. Infect. Immun. 46:224-230.

34. Riley, L. K., and D. C. Robertson. 1984. Brucellacidal activity of human and bovine polymorphonuclear leukocyte granule extracts against smooth and rough strains of Brucella abortus. Infect. Immun. 46:231-236.

35. Rojas, N., E. Freer, A. Weintraub, M. Ramírez, S. Lind, and E. Moreno. 1994. Immunochemical identification of Brucella abortus lipopolysaccharide epitopes. Clin. Diagn. Lab. Immunol. 1:206-213.

36. Sawyer, J. G., N. L. Martin, and R. E. W. Hancock. 1988. Interaction of macrophage cationic proteins with the outer membrane of Pseudomonas aeruginosa. Infect. Immun. 56:693-698.

37. Schurig, G. G., R. Martin Roop II, T. Bagchi, S. Boyle, D. Buhrman, and N. Sriranganathan. 1991. Biological properties of RB51; a stable rough strain of B. abortus. Vet. Microbiol. 28:171-188.

38. Selsted, M. E., D. Szklarek, and R. I. Lehrer. 1984. Purification and antibacterial activity of antimicrobial peptides of rabbit granulocytes. Infect. Immun. 45:150-154.

39. Sipos, D., M. Anderson, and A. Ehrenberg. 1992. The structure of mammalian antibacterial peptide cecropin P1 in solution, determined by protonNMR. Eur. J. Biochem. 209:163-169.

40. Spitznagel, J. K. 1990. Antibiotic proteins of human neutrophils. J. Clin. Invest. 86:1381-1386.

41. Stinavage, P., L. E. Martin, and J. Spitznagel. 1989. O antigen and lipid A phosphoryl groups in resistance of Salmonella typhimurium LT-2 to nonoxidative killing in human polymorphonuclear neutrophils. Infect. Immun. 57: 3894-3900.

42. Takada, K., N. Ohno, and T. Yadomae. 1994. Binding of lysozyme to lipopolysaccharide suppresses tumor necrosis factor production in vivo. Infect. Immun. 62:1171-1175.

43. Thiele, O. W., and G. Schwinn. 1973. The free lipids of Brucella melitensis and Bordetella pertussis. Eur. J. Biochem. 34:333-344.

44. Tsai, C., and C. E. Frasch. 1982. A sensitive stain for detecting lipopolysac- 
charides in polyacrylamide gels. Anal. Biochem. 119:115-119.

45. Vaara, M. 1992. Agents that increase the permeability of the outer membrane. Microbiol. Rev. 56:395-411.

46. Warren, G. H., J. Gray, and J. A. Yurchenko. 1957. Effect of polymyxin on the lysis of Neisseria catarrhalis by lysozyme. J. Bacteriol. 74:788-793.

47. Weber, A., H.-G. Schiefer, and H. Krauss. 1978. Elektronenmikroskopische
Differenzierung der S- und R-Formen von Brucellen durch Behandlung mit polykationischem Ferritin. Zentralbl. Veterinaermed. Reihe B 25:324328.

48. Yamauchi, K., M. Tomita, T. J. Giehl, and R. T. Ellison III. 1993. Antibacterial activity of lactoferrin and a pepsin-derived lactoferrin peptide fragment. Infect. Immun. 61:719-728. 